\title{
Experimental Study on Strength of High Volume High Calcium Fly Ash Concrete
}

\author{
R.Venkatakrishanaiah ${ }^{1}$ G.Mohankumar ${ }^{2}$ \\ ${ }^{I}$ Research Scholar, Department of Civil \& Structural Engineering, Annamalai University, Chidambaram, India \\ (Associate Professor, Civil Engineering, Adhiparasakthi Engineering College, Melmaruvathur) \\ ${ }^{2}$ Professor, Department of Civil \& Structural Engineering, Annamalai University.
}

\begin{abstract}
Fly Ash utilization is a global thinking as its addition to cement concrete supplements for durable concrete. But, most of the Fly Ash utilized and recommended for use in conventional structural concrete including geopolymer concrete is the low calcium fly Ash. The high calcium fly Ash being more cementitious and pozzolanic is used only in non structural applications. The excess calcium if consumed by pozzolanic material may be expected to result in a better concrete. This effect has been studied by replacing silica fume to high volume high calcium fly ash concrete. Conventional M30 grade concrete for cement replacements of $50 \%$ and $60 \%$ with fly-ash by weight and fly ash replacements of $10 \%$ and $20 \%$ with Silica fume was considered. The rate of gain of strength properties up to 365days of curing were obtained for the three categories of concrete and hence thirteen different types of concrete mixes with and without Superplastizers. Addition of silica fume and Superplastizers to high volume high calcium fly ash concrete found to increase the strength properties.
\end{abstract}

Keywords: High volume flyash concrete, high calcium fly ash, Silica fume, Durability

\section{Introduction}

Structural Concrete has been quiet longer used in construction industries for its derived advantages, but the increasing demands on the strength and durability characteristics, tends to make it to accompany with additives or admixtures or both for specific purposes. A new generation concrete having durability and ductility in addition to strength is the current thinking of the concrete researchers.

In 1985, the advanced concrete technology group at CANMET [1] developed high volume fly ash concrete with low water content $(\mathrm{w} / \mathrm{b}$ ratio $<0.4)$ by using super plasticizer. Jerry Stephens, [2] evaluated $100 \%$ fly ash concrete with class C flyash. Halit Yazıc1 et al [3] studied the effect of silica fume and high-volume Class $\mathrm{C}$ flyash on mechanical properties, chloride penetration and freeze-thaw resistance of self-compacting concrete. Tarun Naik et al [4] studied the mechanical and durability properties of concrete incorporating class C flyash from various sources. Fly ash from each source was used at three levels of cement replacements likely 40,50 \& $60 \%$ in producing concrete. Cengiz Duran Atis [5] studied the strength properties of high volume flyash roller compacted and workable concrete and influence of curing condition. Concrete mixes were made with $0 \%, 50 \%$ \& $70 \%$ replacements of OPC with two different low lime class $\mathrm{F}$ flyash with w/c ratios ranged from 0.28 to 0.43 . The compressive, split tensile strength and flexural strength were obtained. Cindy K.Estakhri et al [6] worked on reducing green house gas emissions in Texas with high volume flyash concrete. This study was to determine the potential for reductions in carbon-dioxide emissions in Texas by substituting high volume of fly ash up to $60 \%$ in concrete. However a thorough investigation on the potential use of Class $\mathrm{C}$ for structural concrete is yet to be made. Serkan Subai et al [7] investigated the estimation ability of the effects of utilizing different amount $(0,5,10,15$ and $20 \%)$ of the class $\mathrm{C}$ flyash in cement on the mechanical properties of mortar, like compressive and flexural tensile strength. Approach by artificial neural network and regression methods was made for prediction and the former method found better than the later.

Xue Ying Li et al [8] investigated the use of milled class $\mathrm{C}$ flyash in making geopolymer activated with sodium silicate powder. Compressive strength of $44.6 \mathrm{MPa}$ was obtained with a mass ratio 0.28 of water to milled flyash water (W/F) followed by curing at $70^{\circ}$ for 30 hours. Anjan Chatterjee et al [9] addressed the issues pertaining to the intrinsic quality parameters of the Indian fly ashes, potential of chemical activation, feasibility of adopting the newer milling systems such as vibration and attrition milling, etc.

The main objective of this investigation is to develop a high volume high calcium fly ash concrete with the abundantly available class $\mathrm{C}$ fly ash. The ill effect of class $\mathrm{C}$ fly ash is aimed to be modified with the replacement of fly ash and silica fume. 


\subsection{Cement}

\section{Constituent Materials and Properties}

Ordinary Portland cement of 43 grade conforming to Indian standard IS 12269(1987) was used for the present experimental investigation. Its specific gravity is 3.12.The cement was tested as per the procedure given in Indian standard IS 4031(1988).

\subsection{Fine Aggregate}

Natural river sand conforming to Zone II as per IS 383(1987) was used. The fineness modulus of sand used is 2.84 with a specific gravity of 2.63 .

\subsection{Coarse Aggregate}

Crushed granite course aggregate conforming to IS 383(1987) was used. Maximum size of Course aggregate of $12 \mathrm{~mm}$ was used and the specific gravity of 2.7 and fineness modulus of 5.91 was used.

\subsection{Fly Ash}

Class C Fly ash obtained from Neyveli confirms to IS 3812(1981) was used.

\subsection{Superplasticiser}

In this investigation Polyether-Polycarboxylates (Structuro 203) super plasticizer was used. The super plasticizer (SP) used for the study conforms to IS9103 (1999). The chemical composition of cement, fly ash and silica fume collected is presented in Table 1. The physical properties of cement and fly ash are compared and presented in Table 2. The sample of fly ash and silica fume collected is shown in figure 1. The physical Properties of fine and course aggregates are presented in Table 3.

\section{Mix Design and Concrete Preparation}

The concrete mix has been designed for M30 grade using the provisions of IS $10262-2009$. The proportions of the constituents are arrived as 1:1.06: 2.36 with w/c 0.42 and w/c 0.3 with super plasticizer. Cement replacement of $50 \%$ and $60 \%$ with fly ash by weight was considered. In each category, again fly ash was replaced with silica fume at $10 \%$ and $20 \%$. Totally thirteen different types of concrete mixes were prepared. The quantities of aggregates and water content being the same for all the mixes, the proportions of the cement and the additives are given in Table 4. Slump test was conducted for each mix before casting of the specimens.

Table1. Chemical composition of Cement, Fly Ash and Silica fume

\begin{tabular}{|c|c|c|c|}
\hline \multirow{2}{*}{ Content } & \multicolumn{3}{|c|}{ Composition in } \\
\cline { 2 - 4 } & Cement & C Fly ash & Silica Fume \\
\hline $\mathrm{SiO}_{2}$ & 22.60 & 44.50 & 92.26 \\
\hline $\mathrm{Al}_{2} \mathrm{O}_{3}$ & 04.30 & 21.10 & 0.89 \\
\hline $\mathrm{Fe}_{2} \mathrm{O}_{3}$ & 02.40 & 07.30 & 1.97 \\
\hline $\mathrm{CaO}$ & 64.40 & 12.90 & 0.49 \\
\hline $\mathrm{MgO}$ & 02.10 & 01.60 & 0.96 \\
\hline $\mathrm{SO}_{3}$ & 02.30 & 07.81 & 0.33 \\
\hline $\mathrm{Na}_{2} \mathrm{O}$ & 00.40 & 06.25 & 0.42 \\
\hline $\mathrm{K}_{2} \mathrm{O}$ & 00.20 & 00.80 & 1.31 \\
\hline
\end{tabular}

Table2. Physical Properties of Cement and ny ash

\begin{tabular}{|l|c|c|}
\hline \multirow{2}{*}{\multicolumn{1}{|c|}{ Property }} & \multicolumn{2}{c|}{ Value } \\
\cline { 2 - 3 } & Cement & Fly ash \\
\hline Type & 43 Grade OPC & Class C \\
\hline Normal Consistency & $31 \%$ & $40 \%$ \\
\hline Initial Setting Time (min) & 65 & $150 \mathrm{~min}$ \\
\hline Final Setting Time (min) & 300 & - \\
\hline Specific Gravity & 3.12 & 2.412 \\
\hline Fineness Of Cement By Sieve & $2.5 \%$ & $2.26 \%$ \\
\hline Soundness of cement & $7 \mathrm{~mm}$ & $0.5 \mathrm{~mm}$ \\
\hline
\end{tabular}


Fig 1 Samples of Fly ash and Silica Fume Collected

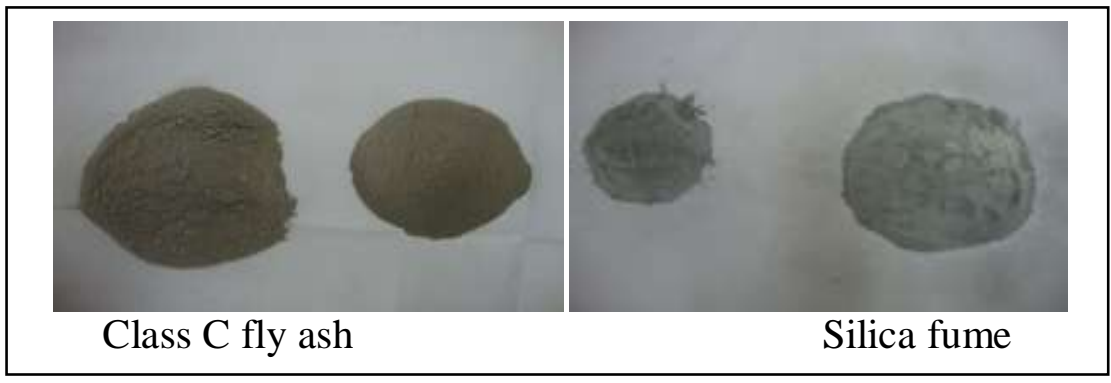

Table3. Physical Properties of Fine and Course Aggregates

\begin{tabular}{|l|c|c|}
\hline \multirow{2}{*}{\multicolumn{1}{|c|}{ Property }} & \multicolumn{2}{c|}{ Value } \\
\cline { 2 - 3 } & $\begin{array}{c}\text { Fine } \\
\text { Agoregate }\end{array}$ & $\begin{array}{c}\text { Course } \\
\text { Agoregate }\end{array}$ \\
\hline Specific Gravity & 2.63 & 2.70 \\
\hline Water Absorption \% & 1.0 & 0.75 \\
\hline Fineness Modulus & 2.86 & 5.91 \\
\hline Impact value & - & 16.12 \\
\hline Uniformity co-efficient & 2.62 & 1.476 \\
\hline Co-efficient of curvature & 0.776 & 1.204 \\
\hline
\end{tabular}

Table4. Mix Proportion for M30 Grade HVHC Fly Ash Concrete

\begin{tabular}{|c|c|c|c|c|c|c|c|c|}
\hline \multirow{2}{*}{\multicolumn{2}{|c|}{ Ingredients }} & \multicolumn{7}{|c|}{ Mix Designation } \\
\hline & & Ml & M2(M2S) & M3(M3S) & M4(M4S) & M5(M5S) & M6(M6S) & M7(M7S) \\
\hline \multicolumn{2}{|c|}{ Cement $\left(\mathrm{kg} / \mathrm{m}^{3}\right)$} & 484.76 & 242.38 & 242.38 & 242.38 & 193.90 & 193.90 & 193.90 \\
\hline \multicolumn{2}{|c|}{ Fly Ash $\left(\mathrm{kg} / \mathrm{m}^{3}\right)$} & 0.0 & 242.38 & 218.14 & 193.90 & 290.90 & 261.77 & 232.68 \\
\hline \multicolumn{2}{|c|}{ Silica Fume $\left(\mathrm{kg} / \mathrm{m}^{3}\right)$} & 0.0 & 0.0 & 24.24 & 48.48 & 0.0 & 29.09 & 58.18 \\
\hline \multirow{2}{*}{ w/b Ratio } & $\mathrm{W} / \mathrm{O} \mathrm{SP}$ & 0.42 & 0.42 & 0.42 & 0.42 & 0.42 & 0.42 & 0.42 \\
\hline & With SP & - & $(0.30)$ & $(0.30)$ & $(0.30)$ & $(0.30)$ & $(0.30)$ & $(0.30)$ \\
\hline \multicolumn{2}{|c|}{ Fine aggregate $\left(\mathrm{kg} / \mathrm{m}^{3}\right)$} & 514.49 & 514.49 & 514.49 & 514.49 & 514.49 & 514.49 & 514.49 \\
\hline \multicolumn{2}{|c|}{ Coarse aggregate $\left(\mathrm{kg} / \mathrm{m}^{3}\right)$} & 1148.58 & 1148.58 & 1148.58 & 1148.58 & 1148.58 & 1148.58 & 1148.58 \\
\hline \multirow{2}{*}{ Water $\left(\mathrm{lit} / \mathrm{m}^{3}\right)$} & $\mathrm{W} / \mathrm{O} \mathrm{SP}$ & 203.6 & 203.6 & 203.6 & 203.6 & 203.6 & 203.6 & 203.6 \\
\hline & With SP & - & $(145.43)$ & $(145.43)$ & $(145.43)$ & $(145.43)$ & $(143.43)$ & $(145.43)$ \\
\hline \multicolumn{2}{|l|}{ SP (\%) } & 0.0 & 1.2 & 1.2 & 1.2 & 1.5 & 1.5 & 1.5 \\
\hline \multirow{2}{*}{ Slump (mm) } & $\mathrm{W} / \mathrm{O} \mathrm{SP}$ & 46 & 12 & 14 & 20 & 0 & 5 & 8 \\
\hline & With SP & - & $(20)$ & (20) & $(22)$ & (18) & (20) & $(20)$ \\
\hline
\end{tabular}

\section{Preparation of Test Specimens}

( ) With SP

The ingredients for various mixes were weighed; required water was added and mixed by using a tilting drum type concrete mixture machine. Precautions were taken to ensure uniform mixing of ingredients. The specimens were cast in steel mould and compacted on a table vibrator. The specimens of

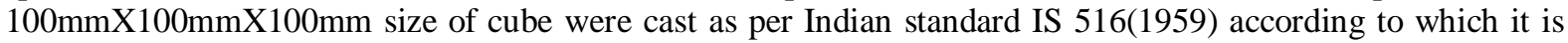
the size to be used for coarse aggregate size of up to $12 \mathrm{~mm}$ for the determination of compressive strength at different ages and for the durability properties. $100 \mathrm{mmdiameter} x 200 \mathrm{~mm}$ long cylinder specimens were cast for the determination of cylinder compressive strength and split tensile strength and $100 \mathrm{mmX} 100 \mathrm{mmX} 500 \mathrm{~mm}$ beam specimens were cast for the determination of flexural strength. Curing of the specimens was started as soon as the top surface of the concrete in the mould was hard enough. Spreading wet gunny bags over the mould for 24 hours after the casting was carried out for the initial curing. The specimen were later demoulded and placed immediately in the water tank for further curing. 


\subsection{Cube and Cylinder Compressive Strength Test}

\section{Mechanical Properties}

$100 \mathrm{~mm}$ cube specimens and $100 \mathrm{~mm}$ diameter $\mathrm{x} 200 \mathrm{~mm}$ long cylinders were casted with out and with super plasticizer and cured for 7,14,21,28,60,90,180,and 360 days. At the end of each curing period, the above specimens were tested in a compression testing machine of $2000 \mathrm{kN}$ capacity under a uniform rate of loading of $140 \mathrm{~kg} / \mathrm{cm}^{2} / \mathrm{min}$. and the compressive strength was calculated as per IS: 516-1959. Figures 3,4,5,6,7,8,9 and 10 shows the variation of cube compressive strength and cylinder compressive strength at various curing periods.

\subsection{Split Tensile Strength Test}

The split tensile strength was determined by subjecting $100 \mathrm{~mm}$ diameter x $200 \mathrm{~mm}$ long cylinders to diametric compression so as to induce uniform lateral tension on the perpendicular plane. At the end of each curing period, the test was conducted as per IS: 5816-1999.

\subsection{Flexural Strength Test:}

The flexural strength tests were carried out on beam specimens of size $100 \times 100 \times 500 \mathrm{~mm}$ under standard two point loading. At the end of each curing period the specimens were tested in flexural testing machine under a uniform rate of loading of $180 \mathrm{~kg} / \mathrm{cm}^{2} / \mathrm{min}$. and the procedure was followed according to IS: 516-1959. All the test results reported in his paper represent the average value obtained from a minimum of three specimens.

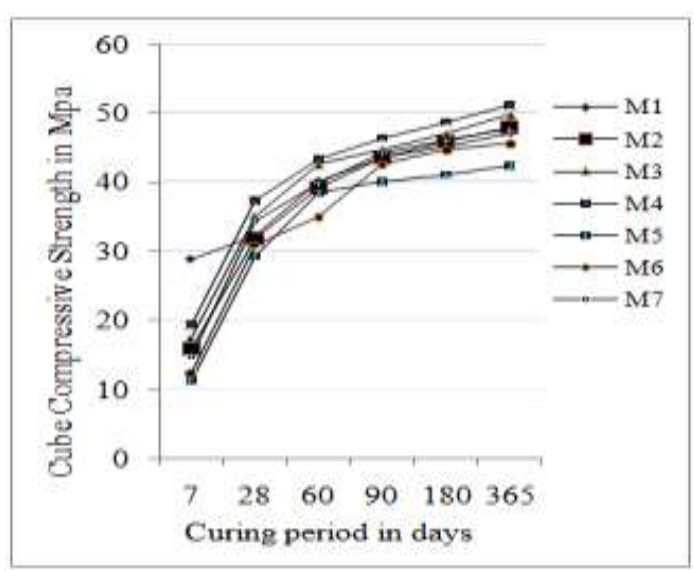

Fig.2: Cube compressive strength without SP

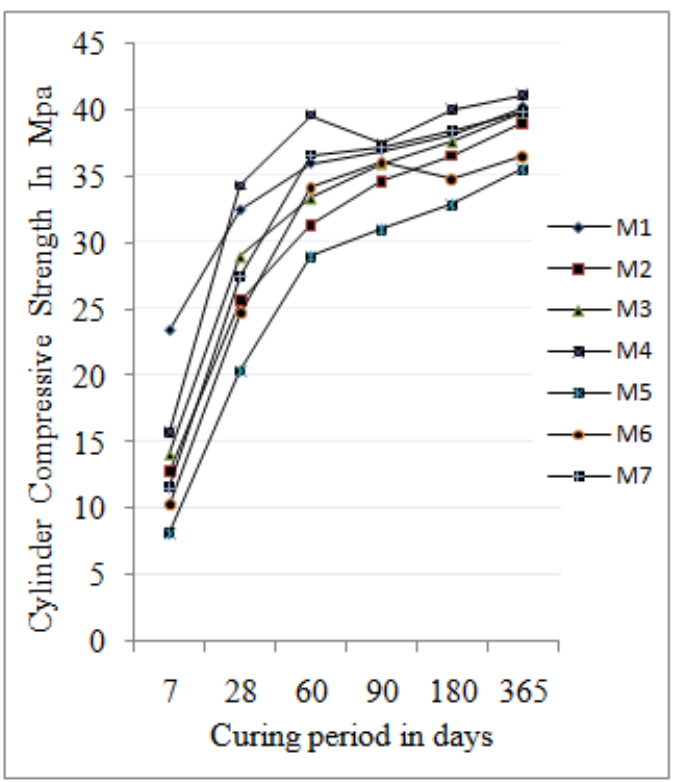

Fig.4: Cylinder compressive strength without SP

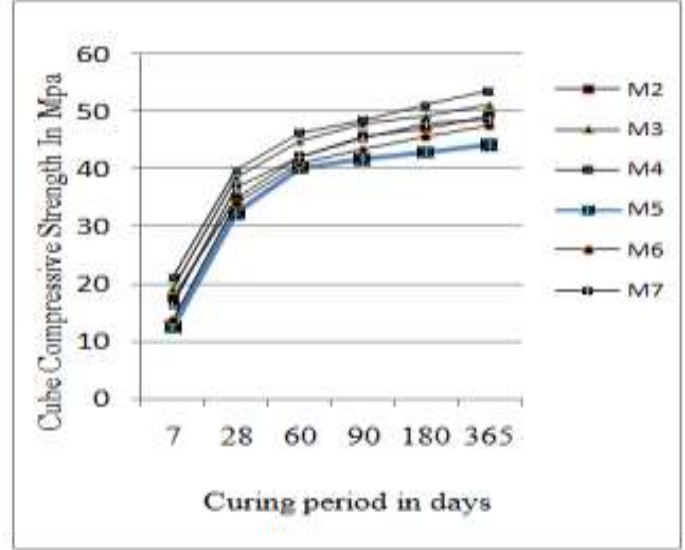

Fig.3: Cube compressive strength with SP

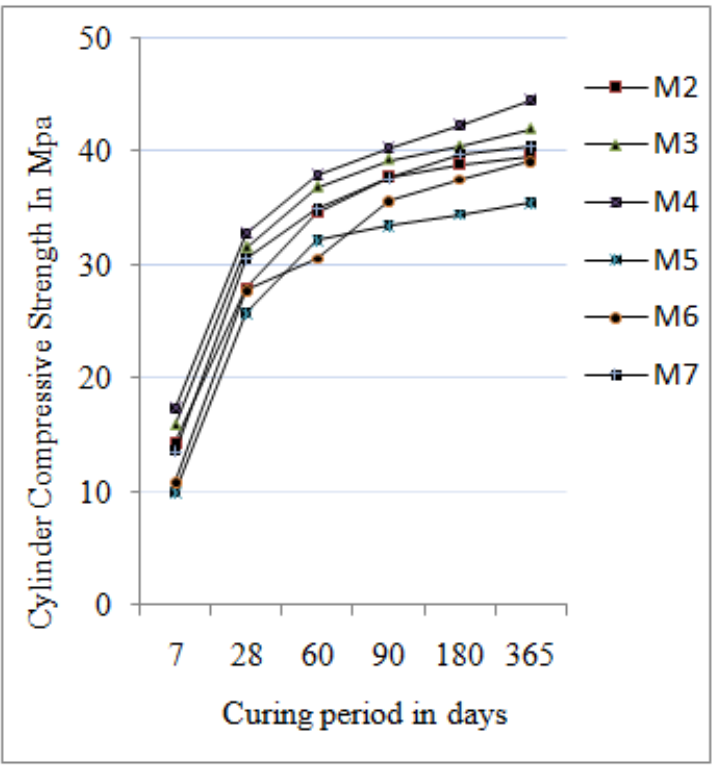




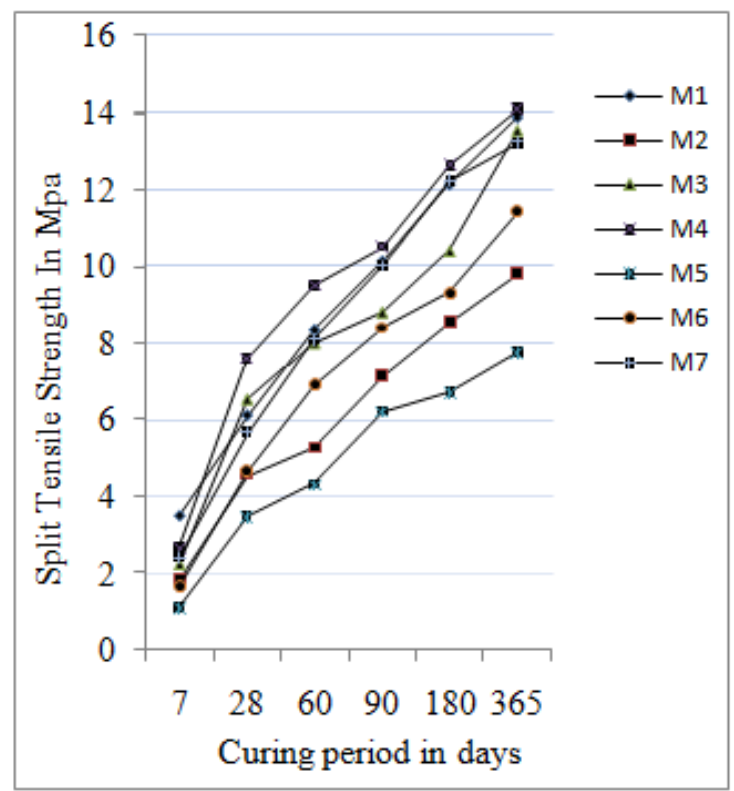

Fig.6:Split Tensile strength without SP

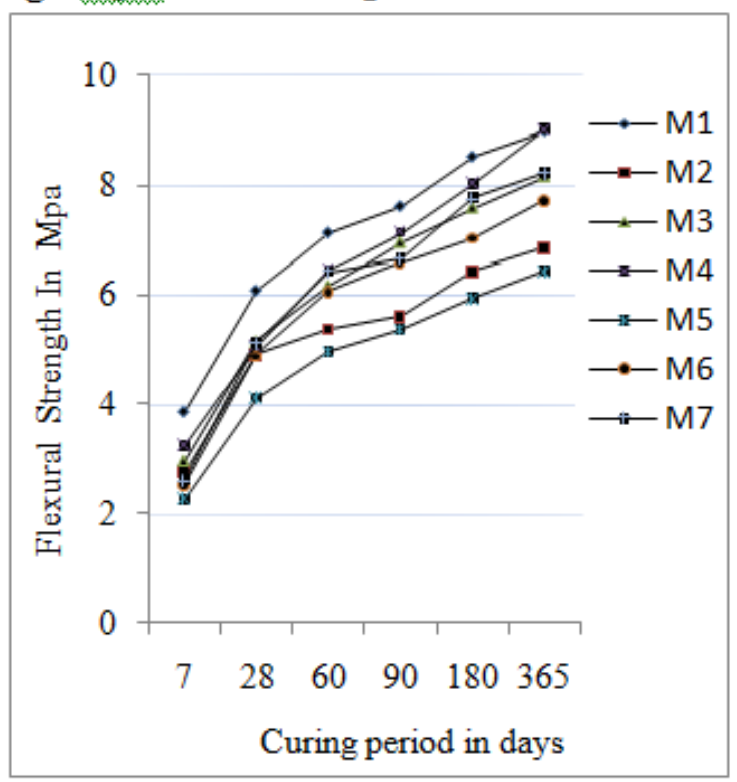

Fig.8:Flexural strength without SP

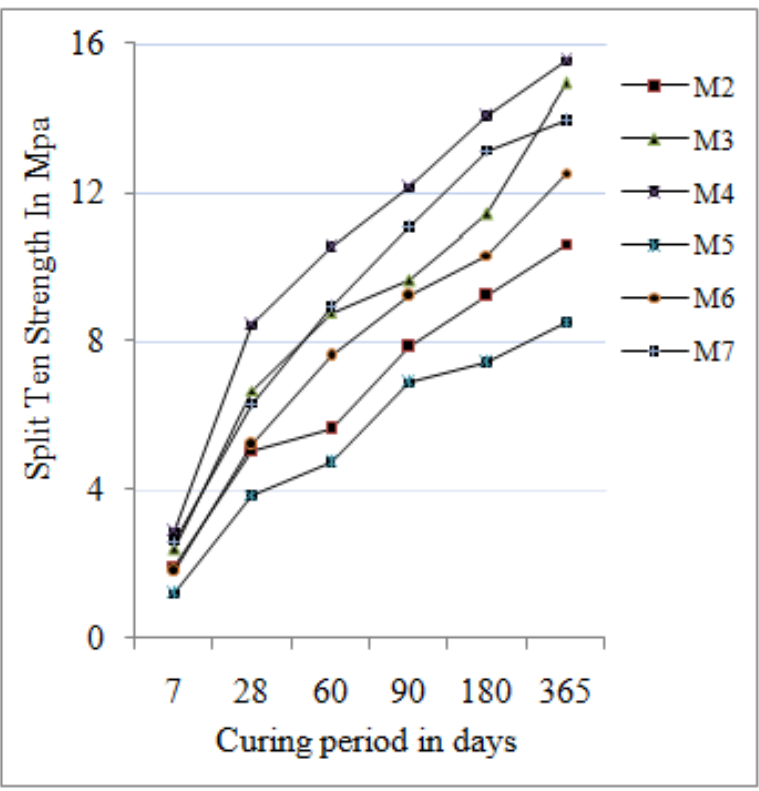

Fig.7:Split Tensile strength with SP

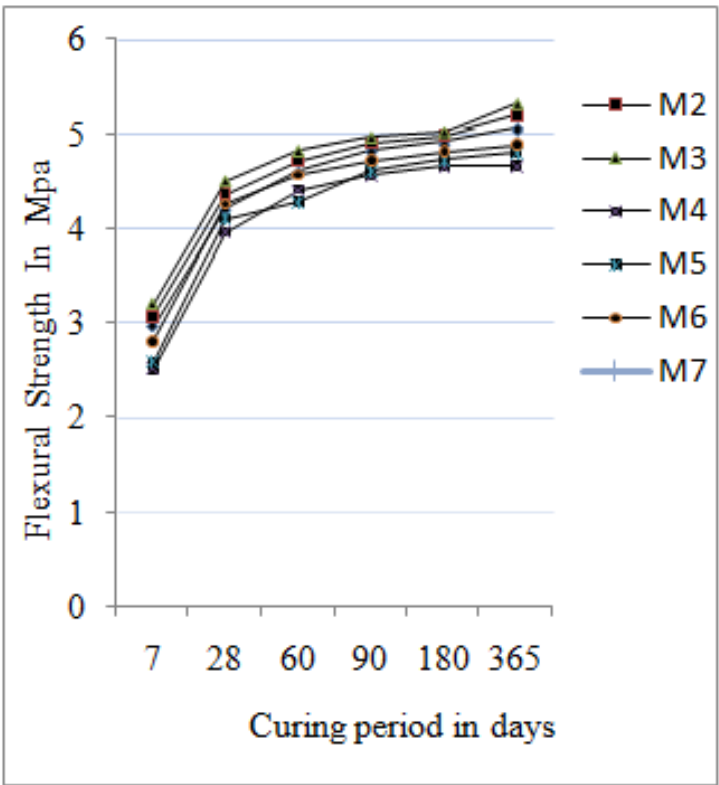

Fig.9:Flexural strength with SP

\section{Results and Discussion}

\subsection{Cube and Cylinder Compressive Strength}

Both Cube and Cylinder compressive strengths at the ages 7,28,60,90,180 and 365 days for all the thirteen series of mixtures without SP and with SP are given in Fig.2 to 5. It is observed that the compressive strength at the age of 7 days for HVHC fly ash concrete mixtures M2 to M7is lower (nearly more than $50 \%$ less) and the strength at the age of 28 days is marginally lower nearly $20 \%$ less for mixes without SP and slightly more for mixtures M3S and M4S with SP when compared to control concrete mix M1.

After the age of 60 days there is a gain in compressive strength for mixtures M3, M3S, M4 and M4S due to the replacement of flyash with silica fume.

However, the strength after 90 days age for mixtures M2 to M7 tend to be more or less same as that of control concrete for mixtures without SP and nearly about $10 \%$ more strength for mixtures M3S and M4S with $\mathrm{SP}$, When compared to control concrete mix M1. 
After the age of 180 days, the gain in strength for mixtures M2, M3 and M4 is about $1.17 \%, 3.80 \%$ and $7.60 \%$ without SP and $4.26 \%, 8.80 \%$ and $12.90 \%$ for the same mixtures with SP. But there is a reduction in compressive strength for mixtures M5 and M6 without SP about $9.22 \%$ and $1.32 \%$ respectively and slightly increase in strength for the same mixtures with SP when compared to control concrete mix M1.

However, the gain in strength after 365 days age for mixtures M2, M3 and M4 is about 1.7\%, 5.52\% and $8.45 \%$ and there is a reduction in strength for mixtures M5 and M6 without SP and gain in strength about $4.88 \%, 8.64 \%$ and $13.91 \%$ for the mixtures M2S, M3S and M4S with SP and also at the same time there is a small gain in strength for the mixtures M6S and M7S with SP, when compared to control concrete mix M1

The reduction in the compressive strength at the ages of 7 and 28 days may be attributed to slower pozzolanic reaction of high volume of fly ash at early ages. However after 28 days of curing the increase in pozzolanic activity of fly ash was sufficient to contribute to the compressive strength (Gopala Krishnan 2001). Thus the efficiency of fly ash and silica fume to act as cementitious material has increased substantially after the age of 28 days and the strength development continues beyond 60 days and stabilizes at the age of almost 180 days.

The cylinder compressive strength also followed the same as cube compressive strength for all mixtures at various ages. The ratio of cylinder compressive strength to cube compressive strength fcy/fcu was determined and it is observed that the ratio fcy/fcu for control concrete at all curing periods was in between 0.81 to0.89. For HVHC fly ash concrete mixtures M2 to M4 without SP was in between 0.785 to 0.92 and for mixtures M5 to M7 without SP was in between 0.693 to 0.917 . The same trend was followed for mixtures M2 to M7 with SP also.

\subsection{Split Tensile Strength of concrete}

The split tensile strength data taken from cylinder specimen of $100 \mathrm{~mm}$ diameter and $200 \mathrm{~mm}$ height at ages 7,28,60,90,180 and 365 days for all mixtures, M1 to M7 without SP and M2S to M7S with SP was shown in Fig 6 and 7. It is observed that for control concrete mixture M1, the split tensile strength varies from 3.5Mpa at 7 days to $13.90 \mathrm{Mpa}$ at 365 days. After 28 days, the percentage gain in split tensile strength for mixture M4 without SP was $24.4 \%$ and for mixture M4S with SP was $37.5 \%$, when compare to control concrete mixture M1. After $60,90,180$ and 365 days it's percentage of gain was gradually reduced as 13.7, 3.70, 4.1 and 1.43 respectively.

\subsection{Flexural strength of concrete}

The flexural strength of concrete at the ages 7, 28, 60, 90, 180 and 365 days for all thirteen series of mixtures with and without SP were shown in Fig.8 and 9. It is observed that the flexural strength of control concrete was varies from $3.84 \mathrm{Mpa}$ at 7 days to $8.97 \mathrm{Mpa}$ at 365 days. But for HVHC fly ash concrete mixtures the strength was marginally lower up to the age of 180 days and then after 365 days this strength is in resulted by $0.56 \%$ for concrete without SP and 5.35 for concrete with SP.

\section{Concluding Remarks}

1. Though the 7 day compressive strength of HVHC fly ash concrete mixture M4 is slightly less than that of the controlled concrete mix, compressive strengths are marginally more than that of the controlled concrete mix at the age of 28 days. After 90 days the rate of gain of compressive strength of the concrete mixtures M1 to M4S is almost the same.

2. $10 \%$ addition of silica fume to HVHC concrete increased the compressive strength and the $20 \%$ addition of silica fume to HVHC concrete has shown higher compressive strength than conventional concrete.

3. The Flexural strength of M30 concrete is found to increase up to a maximum of $6.24 \%$ at replacement of $50 \%$ of cement with flyash and $20 \%$ of flyash with Silica fume after 60 days curing.

4. The Split tensile strength and cylinder Compressive strength of conventional concrete is found to increase up to a maximum of $10 \% \& 7.85 \%$ respectively at replacement of $50 \%$ of cement with flyash and $20 \%$ of flyash with silica fume after 60 days curing.

5. Addition of flyash to the concrete decrease the workability of the concrete and subsequent addition of silica fume increased the workability and strength characteristics.

6. The slight reduction in the workability of the HVHC fly ash concrete mixtures shows that fly ash collection and processing technology in India need to be improved in order to produce good and acceptable quality fly ash with a view to harness the benefits that could accrue by using this material as partial replacement for cement in concrete mixtures. Also the super plasticizer (structuro 203) shows better performance to increase workability and strength and to reduce permeability of HVHC fly ash concrete mixtures.

7. Addition of silica fume to the HVHC concrete increased the workability and strength characteristics and reduced the water absorption. 


\section{References}

[1] Kumar Mehta.P (2004). High-performance, High-Volume Fly ash Concrete for Sustainable Development, Proceedings of the Nelu Spiratos Symposium, Committee for the Organization of CANMET/ACI Conferences.

[2] Jeryy Stephens (2006). Evaluation of 100\% Fly Ash concrete, Montana State University, 406: 994-6113.

[3] Halit Yazıc1(2008). 'The Effect of Silica Fume and High-Volume Class C FlyAsh on mechanical Properties, Chloride Penetration And Freeze-Thaw Resistance Of Self-Compacting Concrete', Construction and Building Materials, Volume 22, Issue 4, , Pages 456-462

[4] Tarun Naik, Shiw Singh and Mohammad Hossain (1994). The Mechanical and Durability Properties of Concrete Incorporating Class C Fly Ash from Various Sources, CBU-1994 - 14.

[5] Cengiz Duran Atis (2005). Strength Properties of High Volume Fly Ash Roller Compacted And Workable Concrete And Influence of Curing Condition, Cement and Concrete Research, Vol.35(6).

[6] Cindy K.Estakhri, Donald Saylak (2005). Reducing Greenhouse Gas Emissions in Texas With High Volume Fly Ash Concrete. Transportation Research Record No.1941, 2005:167-174.

[7] Serkan Subar (2009). Prediction of mechanical properties of cement containing class C flyash by using artificial neural network and regression technique, Scientific Research and Essay Vol. 4 (4); 289-297, ISSN 1992-2248.

[8] XueYing Li., EnZu Zheng., YaDing Zhao and ChunLong Ma (2011). Strength and microstructure of class C flyash based geopolymer activated with sodium silicate powder, IEEE International Conference on Consumer Electronics, Communications and Networks (CECNet-2011), 16-18April 2011, XianNing, China, (ISBN: 978-1-61284-457-2). pp. 1672-1675.

[9] Anjan K. Chatterjee (2010) Indian Flyashes, Their Characteristics, and Potential for Mechano-Chemical Activation for Enhanced Usability, Proceedings, Second international conference on sustainable construction materials and technologies, 28-30 ${ }^{\text {th }}$ June 2010, Universita politechnic, delle marche, Ancona, Italy. 